Kolyubakina L. V., Khilchevska V. S. Simulation training of interns-pediatricians: assessment and stabilization of urgent conditions in neonatology. Journal of Education, Health and Sport. 2020;10(3):173-176. eISSN 2391-8306. DOI http://dx.doi.org/10.12775/JEHS.2020.10.03.019

https://apcz.umk.pl/czasopisma/index.php/JEHS/article/view/JEHS.2020.10.03.019

https://zenodo.org/record/3749336

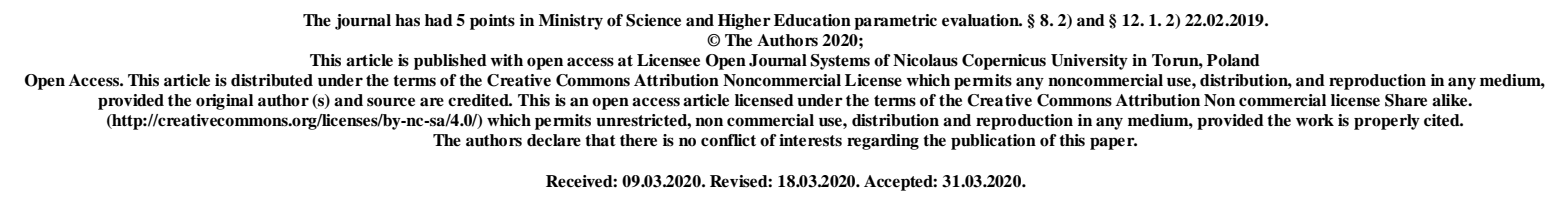

UDC 616-08-039.74:616-053.2:378.147

\title{
SIMULATION TRAINING OF INTERNS-PEDIATRICIANS: ASSESSMENT AND STABILIZATION OF URGENT CONDITIONS IN NEONATOLOGY
}

\author{
L. V. Kolyubakina
}

$\mathrm{PhD}$, Associate Professor, Department of Pediatrics and Children Infectious Diseases

HSEE of Ukraine «Bukovinian State Medical University»

\section{V.S. Khilchevska}

$\mathrm{PhD}$, Associate Professor, Department of Pediatrics and Children Infectious Diseases

\section{HSEE of Ukraine «Bukovinian State Medical University»}

\section{Abstract}

The article presents the results of applying stimulation technology in basic training of interns on specialty "Pediatrics" on giving urgent aid in case of neonatal asphyxia.

Objective: to analyze the efficacy of introducing the elements of simulation training of interns on specialty "Pediatrics" at the Department of Pediatrics and Children Infectious Diseases, Higher State Educational Establishment of Ukraine "Bukovinian State Medical University".

Materials and methods. The authors share their experience in introducing approaches to assessment and stabilization of condition of a neonate with severe asphyxia applying simulation methods of training.

Results. The interns admitted a high efficacy of simultaneous learning theoretical material and mastering practical skills on a simulation mannequin. The results of testing in 
"KROK-3" frame were found to be higher after simulation practice and its discussion (on an average $80,5 \%$ in comparison with $72,2 \%$ before training).

Conclusions. In training interns' skills of urgent aid given to neonates both clinical protocols developed on the evidence-based principals and modern simulation technologies are reasonable to be used.

\section{Key words. Simulation training; interns; neonatology; asphyxia.}

Introduction. One of the major issues in professional training of medical workers is intensification of their practical aspects. Traditionally graduates of higher medical institutions have their practical training working with patients at training medical facilities. Usually such kind of training method is an effective one, though there are certain shortcomings. The main of them are the lack of planned patients, the necessity to obtain parents' consent to perform examination and manipulations, a long objective evaluation of practical skills by an instructor $[1,3]$.

Nowadays training of doctors in certain fields is practically impossible without application of simulation technologies. Possibility of their introduction into training enables to master practical skills without any risk for patients in the situations closely related to those of real urgent clinical ones, analyze errors with revision of a clinical situation considering individual peculiarities of interns, acquire tactile sensitivity and develop memory [4,5]. All these facts promote internal motivation to cognitive processes, form clinical thinking and professional competence.

The major issues of neonatology and urgent conditions of neonates in particular, constitute an important part of training during internship. Learning the topic "Asphyxia of Neonates" using imitation methods of training increases efficacy of giving urgent aid in neonatology [2], forms an accurate algorithm of practical actions in critical situations as well as skills of a team work.

Objective: to analyze the efficacy of introducing the elements of simulation training of interns on specialty "Pediatrics" at the Department of Pediatrics and Children Infectious Diseases, Higher State Educational Establishment of Ukraine "Bukovinian State Medical University".

Materials and methods. 15 interns-pediatricians of the $1^{\text {st }}$ year of training participated in the simulation class on the subject «Primary Resuscitation Aid for Neonates». Simulation training included testing of the initial level of knowledge by means of solving tests in "KROK-3. General Medical Training” frame, organization of a clinical scenario, training in 
the form of solving a clinical situation (severe asphyxia of a neonate), discussion of the results obtained considering errors in giving urgent medical aid, and demonstration of a topical video. After training the interns were suggested to be tested again in order to evaluate the dynamics of knowledge obtained.

Results and discussion. A scenario of primary resuscitation aid given to neonates has been developed at the Department of Pediatrics and Children Infectious Diseases. The scenario includes detection of the necessity for primary aid given to neonates in case of asphyxia under conditions of discharge of clean amniotic fluid, providing a correct neonate's position, sanitation of the upper respiratory tract (catheter, nasogastric tube), assessment of the need to respiratory support followed by the evaluation of its efficacy, defining indications for external cardiac massage, substantiation of giving medicines (epinephrine, 0,9\% sodium chloride solution) with detection of the ways and doses to be administered.

The teams were formed including 2 doctors and 1 nurse. Team work was assessed. In the process of training the roles and duties were redistributed and it enabled to make an effective decision and complete the task according to the algorithm of resuscitation neonatal aid.

In the process of debriefing Pendleton's model of feedback was used in training of physicians during simulation scenarios [4]. The instructor participated in discussion focusing on the most common errors while working in this algorithm of actions. The interns admitted that the introduced method of training reproduces a real patient with assessment of vital functions. It enables them to acquire clinical experience applying their knowledge and abilities.

Before participation of interns in stimulation scenario the initial level of their knowledge was evaluated by means of testing. It allowed the instructor to concentrate attention on the most complicated issues in neonatal resuscitation. After simulation practical training and its discussion the interns were tested again. The results appeared to be higher (on an average $80,5 \%$ in comparison with $72,2 \%$ before training). The result was found to be higher than that of the initial level in $67,0 \%$ of cases, and in the rest $33,0 \%$ it remained unchanged, which required further training of the clinical algorithm.

Advantages and disadvantages of training, formation of skills to assess the patient's condition, identification and stabilization of vital functions in case of asphyxia of neonates were discussed together with the interns who were trained according to the scenario. All the participants admitted a high level of reality of simulation training and high efficacy of consolidation of theoretical knowledge with simultaneous formation of manual skills. The 
interns expressed an opinion on the necessity to increase the amount of practical hours using simulation mannequins in the program of post-graduate training which would decrease the risk of medical errors in their further practical work.

Conclusion. Therefore, simulation technologies in training interns can be applied as a constituent part of their practical training, the method promoting formation of clinical thinking and professional competence. In training interns' skills of urgent aid given to neonates both clinical protocols developed on the evidence-based principals and modern simulation technologies are reasonable to be used. Moreover, organization of simulation scenarios on giving urgent aid during internship is rather effective mechanism for preparation to the Licensed Integrated Exam @ KROK-3. General Medical Training».

\section{References.}

1. Starets EA., Kotova NV., Loseva EA., Fedorenko OV. Simulyaczionnoe obuchenie v pediatrii i neonatologii: oczenka, raspoznavanie i stabilizacziya neotlozhny`kh sostoyanij $\mathrm{u}$ detej. [Simulation Training in Pediatrics and Neonatology: Assessment, Identification and Stabilization of Urgent Conditions in Infants]. Zdorov`e rebenka, 2018;4 (13):405-410.

2. The Order of the Ministry of Health of Ukraine № 225 dated 28.03.2014, Unifikovanij klinichnij protokol "Pochatkova, reanimaczijna i’ pislyareanimaczijna dopomoga novonarodzhenim v Ukrayini'["Unified Clinical Protocol "Primary, Resuscitation and Post-Resuscitation Neonatal Aid in Ukraine"].

3. Zhuravleva LV., Lopina NA. Praktichno-oriyentovanij kejs-metod navchannya v sistemi bezperervnoyi medichnoyi osviti na osnovi informaczijno-osvitnikh veb-tekhnologij yak sposib simulyaczijnogo navchannya : navch.-metod. posibnik dlya vikladachiv med. osvitnikh zakladiv [Practically Oriented Case Method of Training in the System of Continuous Medical Education on the Basis of Information-Educational Web-Technologies as a Means of Simulation Training: Educational-Methodical Manual for Teachers of Medical Educational Institutions]. - Kharkiv: KNMU, 2019. - 76 p.

4. Sørensen JL, Ostergaard D, LeBlanc V, et al. Design of simulation-based medical education and advantages and disadvantages of in situ simulation versus off-site simulation. BMC Med Educ. 2017 Jan 21;17(1):20.

5. Simulyaczijna mediczina. Dosvid. Zdobuttya. Perspektivi. Praktichnij poradnik. [Simulation Medicine. Experience. Achievements. Prospects. Practical Advisor]. Sumy: Publishing House "Universytetska Knyha", 2018. 240 p. 